Primljen / Received: 13.7.2017. Ispravljen / Corrected: 2.10.2017.

Prihvaćen / Accepted: 16.3.2018. Dostupno online / Available online: 10.5.2018.

\section{Analysis of water exchange via pipe culverts in Opatija marina}

Authors:

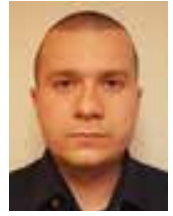

${ }^{1}$ Damjan Bujak, MCE dbujak@grad.hr

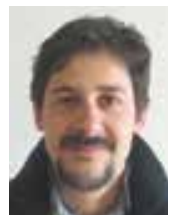

${ }^{1}$ Assist.Prof. Dalibor Carević, PhD. CE car@grad.hr

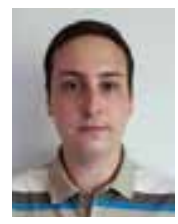

${ }^{1}$ Ratko Ramuščak, MCE ratko.ramuscak@student.grad.hr

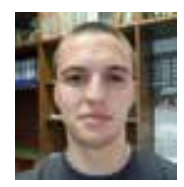

${ }^{1}$ Tin Kulić, MCE tin.kulic@student.grad.hr

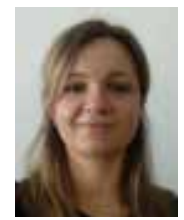

IIvana Bartolić, MCE ibartolic@tvz.hr

'University of Zagreb

Faculty of Civil Engineering

ZZagreb University of Applied Sciences

Department of Civil Engineering

\section{Damjan Bujak, Dalibor Carević, Ratko Ramuščak, Tin Kulić, Ivana Bartolić}

Professional paper

\section{Analysis of water exchange via pipe culverts in Opatija marina}

In areas with small tidal oscillations (such as the Mediterranean Sea), the exchange of water in harbours can be improved by pipe culverts incorporated in breakwaters. The effect of natural factors on water exchange was tested via in-situ measurements conducted in Opatija marina. It was established that the flow in partly submerged pipe culverts exceeds by two times the flow in a fully submerged pipe culvert. In the period without wind and waves, almost three percent of the total volume circulates through a pipe culvert during a single tidal oscillation.

Key words:

water exchange, pipe culverts, wind, breakwater, wind-generated waves

Stručni rad

Damjan Bujak, Dalibor Carević, Ratko Ramuščak, Tin Kulić, Ivana Bartolić

\section{Analiza izmjene vode kroz cijevne propuste u marini Opatija}

U područjima s malim oscilacijama plime i oseke (npr. Sredozemno more), izmjena vode u lučicama može se poboljšati pomoću cijevnih propusta ugrađenih u lukobranima. Utjecaj prirodnih čimbenika na izmjenu vode ispituje se pomoću terenskih mjerenja provedenih u marini Opatija. Ustanovljeno je kako protok u djelomično potopljenom cijevnom propustu raste dvostruko više u odnosu na protok u potpuno potopljenom cijevnom propustu. U razdoblju bez vjetra i valova, približno 3 \% ukupnog volumena cirkulira kroz cijevni propust tijekom jedne plimne oscilacije.

Ključne riječi:

izmjena vode, cijevni propusti, vjetar, lukobran, valovi generirani vjetrom

Fachbericht

Damjan Bujak, Dalibor Carević, Ratko Ramuščak, Tin Kulić, Ivana Bartolić

\section{Analyse des Wasseraustauschs durch die Rohrdurchlässe in der Marina Opatija}

In den Gebieten mit geringen Flut- und Ebbeschwankungen (z. B. Mittelmeer) kann der Wasseraustausch in den Häfen durch Rohrdurchlässe, die in den Hafendamm eingebaut sind, verbessert werden. Der Einfluss natürlicher Faktoren auf den Wasseraustausch wird mithilfe von Feldmessungen, die in der Marina Opatija durchgeführt wurden, untersucht. Festgestellt wurde, dass der Durchfluss in den teilweise versenkten Rohrdurchlässen im Vergleich zum Durchfluss in vollständig versenkten Rohrdurchlässen doppelt so stark ansteigt. Im Zeitraum ohne Wind und Wellen fließen etwa 3\% des Gesamtvolumens durch die Rohrdurchlässe während einer Flutschwankung.

Schlüsselwörter:

Wasseraustausch, Rohrdurchlass, Hafendamm, durch Wind generierte Wellen 


\section{Introduction}

Water quality in basins can deteriorate due to growing human activities that take place in water basins. Marinas and harbours near urban areas along the coast are under high anthropogenic pressure, with a relevant impact on their water quality [1]. Environmental pollution is produced by high anthropogenic pressure near urban areas through economic and commercial activities. Contamination modifies the quality of water and its natural characteristics, and so pollution concentrations should be monitored and reduced. Degraded water quality can lead to reduced amounts of dissolved oxygen, which favours development of algae and may consequently endanger the ecosystem $[2,3]$. Water quality degradation in harbours is conditioned by interactions between several types of harbour activities. For example, vessel traffic, cargo freight, bunkering, and other activities, determine potential degradation of water quality.

Harmful effects on water quality within a harbour can be avoided by maintaining an optimum water renewal rate or by reducing potential sources of pollutants [4]. Water renewal in marine systems has demonstrated to be a critical factor controlling behaviour of chemical and biological variables of the ecosystem $[5,6]$. The water renewal in an enclosed domain is controlled by the corresponding natural influences (tides, wind stresses, waves, atmospheric fluxes, external currents, inner freshwater discharge, etc.). Understanding water circulation makes it possible to investigate effectiveness of hydrodynamic action in removing any substance introduced into a water body [7].

Scientific literature offers various explanations and empirical methods for calculating the flushing capacity, based either on hydrodynamic or morphological characteristics. Most water renewal prediction methods are fundamentally based on tidal action as the dominant generator of water renewal [8-10], allowing differentiation of marinas and harbours located at different latitudes. The water flushing rate is also affected by structural factors such as the plan form geometry of a harbour, entrance dimensions of a harbour, water depth, bed slope, etc., what has already been well investigated in relevant literature [11-13]. In areas like the Mediterranean and the Adriatic Sea, tidal oscillations are significantly smaller and therefore water renewal is also reduced. In these areas, it is common to use flushing culverts (pipes or rectangular openings in a breakwater body, $\sim 1 \mathrm{~m}$ in diameter) $[14,15]$ to improve water renewal. Possibly the most dominant mechanism of sea water exchange in harbours with low tides involves wind action. Research on numerical models shows that a beneficial impact on water renewal (in two inlet basins) may come with the occurrence of wind generated local rise (tilt) in sea level within the basin [16]. For example, in Venice, the wind blowing from the northeast creates a surface tilt from the northern area towards the southern area. When the tilt is present, a steady circulation is created and the water enters the northern inlet and leaves the southern one, improving water renewal [17]. It was also concluded that wind does not significantly contribute to water renewal in confined one-inlet systems where the wind is mainly mixing the enclosed seawater, especially when comparison is made to studies in the Venetian lagoon that has multiple inlets $[16,18]$.
The mixing efficiency is a function of the morphology of the basin, influence of wind, and sea stratification. Experimental research was conducted in a wave flume to investigate wave energy transmission through flushing culverts, as waves may also play a significant role in water renewal through flushing culverts [14]. Although it has often been assumed that wave energy transmission translates into mass flow rate through the culvert, some studies show that there might not be a correlation between the two [19]. It comes as no surprise that most research on culvert hydrodynamics is conducted in the area of the Mediterranean Sea, where low tidal oscillations are a common engineering challenge. The purpose of culverts is to enable the exchange of the open sea water and the sea water contained within a protected maritime zone. Flushing culverts are the most cost-effective method used in port engineering to improve water renewal in harbours.

Extensive studies have been made on the design and application of flushing culverts as a part of river hydraulics regarding entrance and exit loss coefficients, and their sensitivity to culvert damage and changes in water level in front of the culvert [20-23]. Unfortunately, none has proven its applicability in maritime conditions.

In this paper, the influence of various natural flow generators on flushing time is investigated using field measurements conducted in real conditions in Opatija Marina. Volumes of sea water passing through culverts, as related to wind data, were registered and analysed.

\section{Field measurements}

Field measurements were conducted in ACl Opatija Marina in Croatia (Figure 1). The marina has a set of 8 parallel culverts $1 \mathrm{~m}$ in diameter, appropriately installed in a rubble mound breakwater. Flushing culverts were constructed in this marina because of the low tide range present at the location, so as to enable a more efficient water renewal. The top of the culverts was placed at the mean sea level. The culverts themselves are installed at the end opposite to the inlet (entrance into the marina) but are not in the same direction as the inlet normal (the direction of the culvert and the inlet normal roughly define a right angle). The tidal amplitude is dominantly about 0.4 meters during the measurement period. The sheltered area (about $40000 \mathrm{~m}^{2}$ ) extends to about 350 m alongshore and $150 \mathrm{~m}$ across-shore, and the average depth of the basin is $5 \mathrm{~m}$. The marina is connected to the Adriatic Sea by one $30 \mathrm{~m}$ wide entrance and 8 flushing culverts. The Opatija Marina also has a favourable location in terms of water renewal, as sirocco (SE) and bora (NE) winds are very frequent.

Field measurements enable a good insight into the processes that could otherwise hardly be captured and measured in laboratory, i.e. wind influence, combined influence of wind and wave action, and some other phenomena that can be observed in nature only. Five Acoustic Doppler Current Profilers (ADCPs), one portable flow measurement system (PCM4), one anemometer, one CTD probe, and a time lapse camera, were installed in Opatija Marina on 15.2.2017. and measurements were continuously made until 31.3.2017 when the measuring devices were removed (Figure 1). The PCM measurements ended earlier (on 21.3.2017.) as the battery power was depleted. 


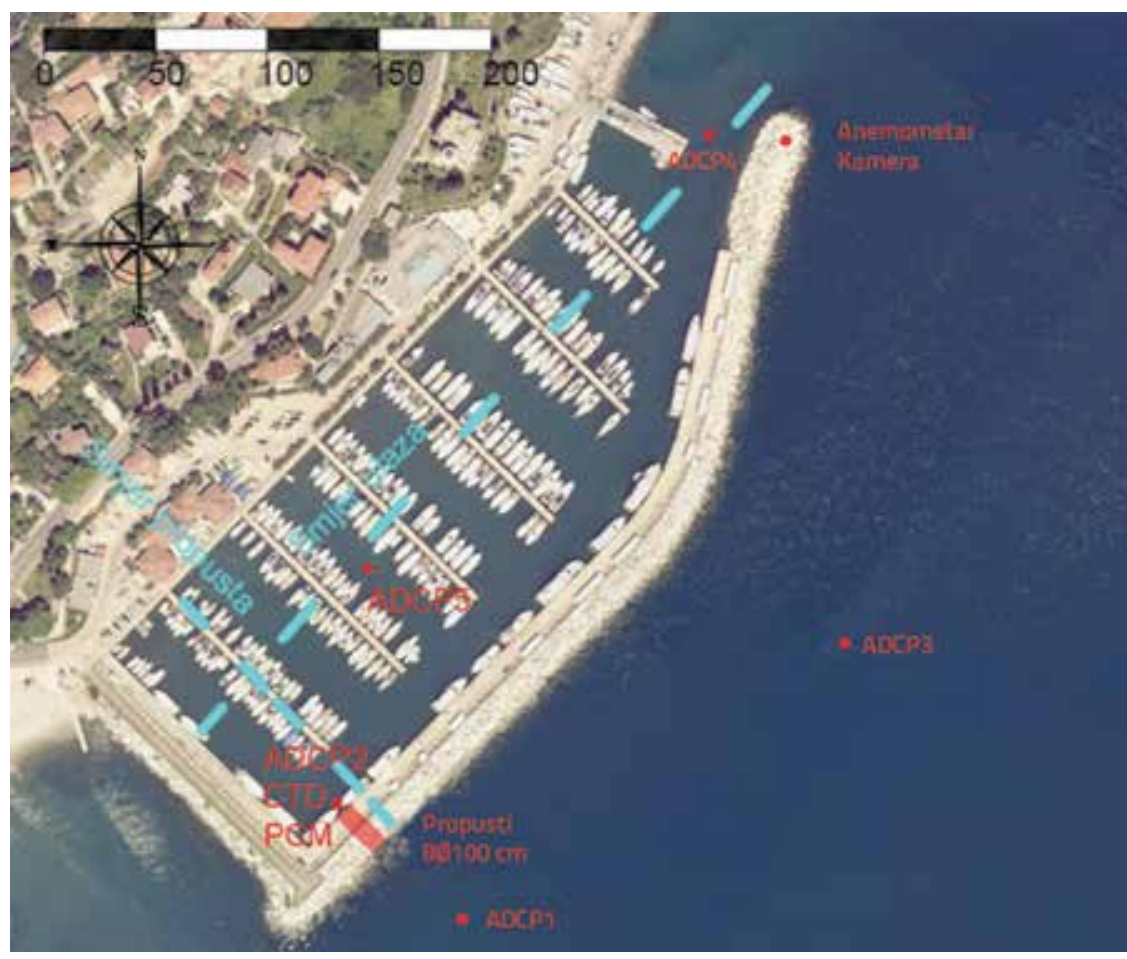

Figure 1. Plan view of ACI Opatija Marina with locations of measuring devices

Table 1. Sampling and output rates of measuring devices deployed at Opatija Marina

\begin{tabular}{|c|c|c|}
\hline Measuring device & Sampling rate & Output rate \\
\hline ADCP 1, 2 & 1 second & $\begin{array}{l}\text { wave - } 15 \text { minutes, } \\
\text { currents - } 10 \text { minutes }\end{array}$ \\
\hline $\operatorname{ADCP} 3,4,5$ & 1 second & currents - 10 minuta \\
\hline CTD & 1 second & 1 second \\
\hline Anemometer & 1 second & 1 second \\
\hline PCM & $\begin{array}{c}\text { varies with hydraulic and physical } \\
\text { conditions }\end{array}$ & 2 minutes \\
\hline
\end{tabular}

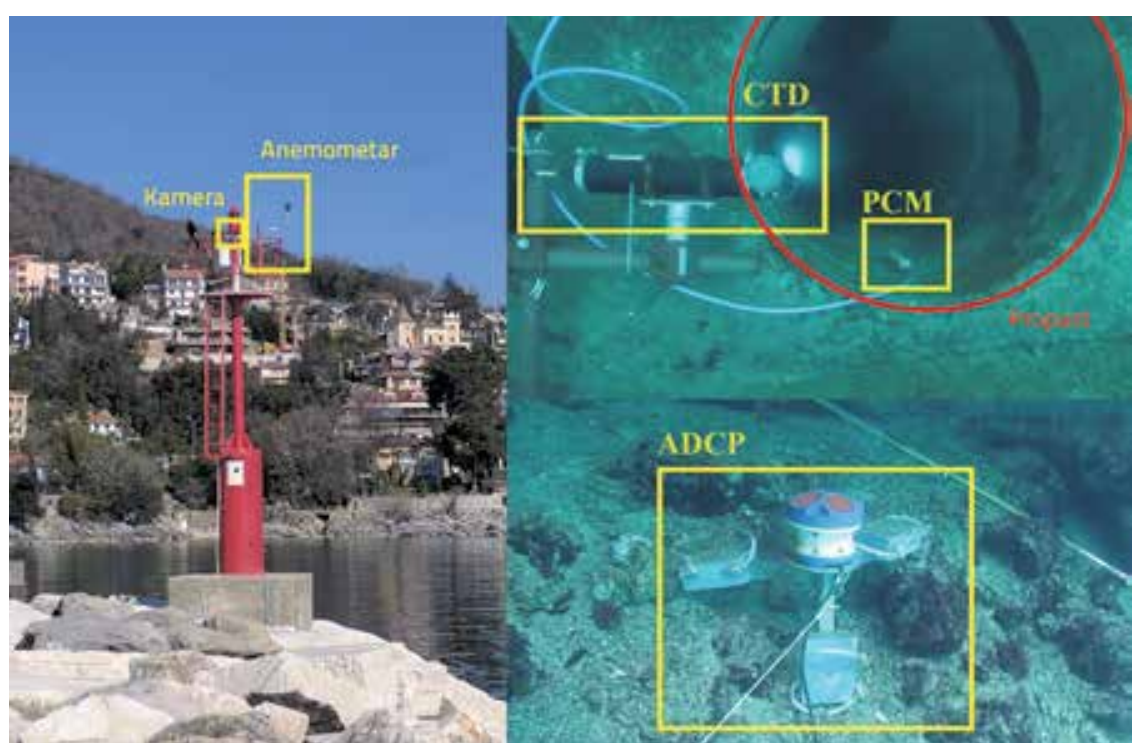

Figure 2. Measurement devices (ADCP2, PCM, CTD, Anemometer and a time lapse camera) mounted at their respective positions at Opatija Marina
Two out of five ADCPs were placed at each side of the flushing culvert (ADCP1 and $A D C P 2)$, one was placed at the centre of the marina (ADCP5), one at the inlet to the marina (ADCP4), and one approximately 100 meters to the west of the primary breakwater (ADCP3). ADCPs 1 and 2 measured wave conditions (wave height, peak wave period, and direction of the peak wave period) and currents, while the others measured currents only. The PCM sensor was placed inside one of the eight culverts present in the marina. It measured velocities, flow, and the level inside the culvert. The PCM provides valuable information about the flow rate that can be later linked with the effects of various natural generators of flow (e.g. wind, waves and tidal oscillations). The anemometer was placed on a higher position at the head of the breakwater, so as not to be obstructed by marina infrastructure. The anemometer measured wind velocities and directions in the horizontal plane. In the measurement period, the number of vessels in the marina and their positions were captured by a time lapse camera positioned next to the anemometer (Figure 2). CTD measurements at the culvert showed a stratified state inside the marina. Below the depth of 30 $\mathrm{cm}$ the salinity was a constant $38 \mathrm{~g} / \mathrm{kg}$, but near the surface the salinity dropped almost to $15 \mathrm{~g} / \mathrm{kg}$. Temperature did not show any change with depth during the measuring period. This dramatic change in salinity at the surface is probably due to the previously documented freshwater springs present at the bottom of the basin and the seawall. The fresh water is probably caused by rainfall in the hinterland that quickly runs through the karst and forms a thin layer of fresh water at the sea surface inside the basin. No estimations have been made so far about the amount of fresh water that enters the basin during dry or rainy periods. The sampling (time of ping) and output rates of measuring devices varied depending on the battery consumption and power availability for certain devices (Table 1). The raw data collected by all instruments were first submitted to hourly averaging. This assumption is considered reasonable because flushing times of most harbours and marinas are in the order of tens of days. 


\section{Results and discussion}

Five characteristic periods with significant wind (characteristic periods 2 to 6 shown in Figure 3 and Table 2) were registered by all instruments in the measurement period (the battery of the PCM flow measuring instrument was fully depleted already on 21.3.2017, while other devices were steadily recording until their removal on 31.3.2017) (Figure 3).

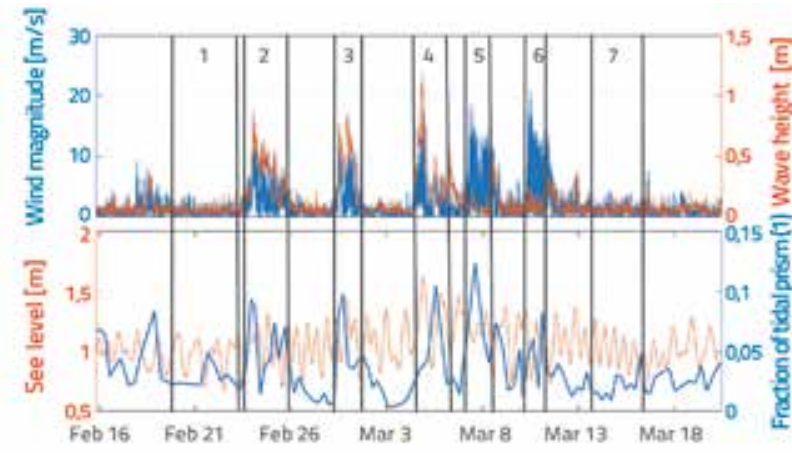

Figure 3. Measured time series of wind velocity (at the head of the breakwater), significant wave height (at the leeward side of the culvert by ADCP1), sea level (inside the culvert by PCM) and volume of sea that passes through the culvert during one tidal flood/ebb as a fraction of tidal prism; with seven characteristic periods

Two representative periods without wind were also considered, so as to observe the flow in the culvert forced by tidal oscillations and baroclinic circulation only (characteristic periods 1 and 7 shown in Table 2). It can be noted that high values of significant wave height (measured by ADCP1 at the seaward side of the culvert) do not always follow wind velocity trends. The first three characteristic periods with wind present $(2$, 3 , and 4) produce waves up to 1.2 meter in height with good agreement between the wave height and wind velocity. While the last two characteristic periods with wind present (5 and 6) mostly did not produce any significant wave heights, the waves approaching from the southeast-east were observed at the end of each characteristic period. The waves appeared because the wind changed direction at the end of wind events 5 and 6 from NNE to SEE, where enough fetch length was available for wave generation.

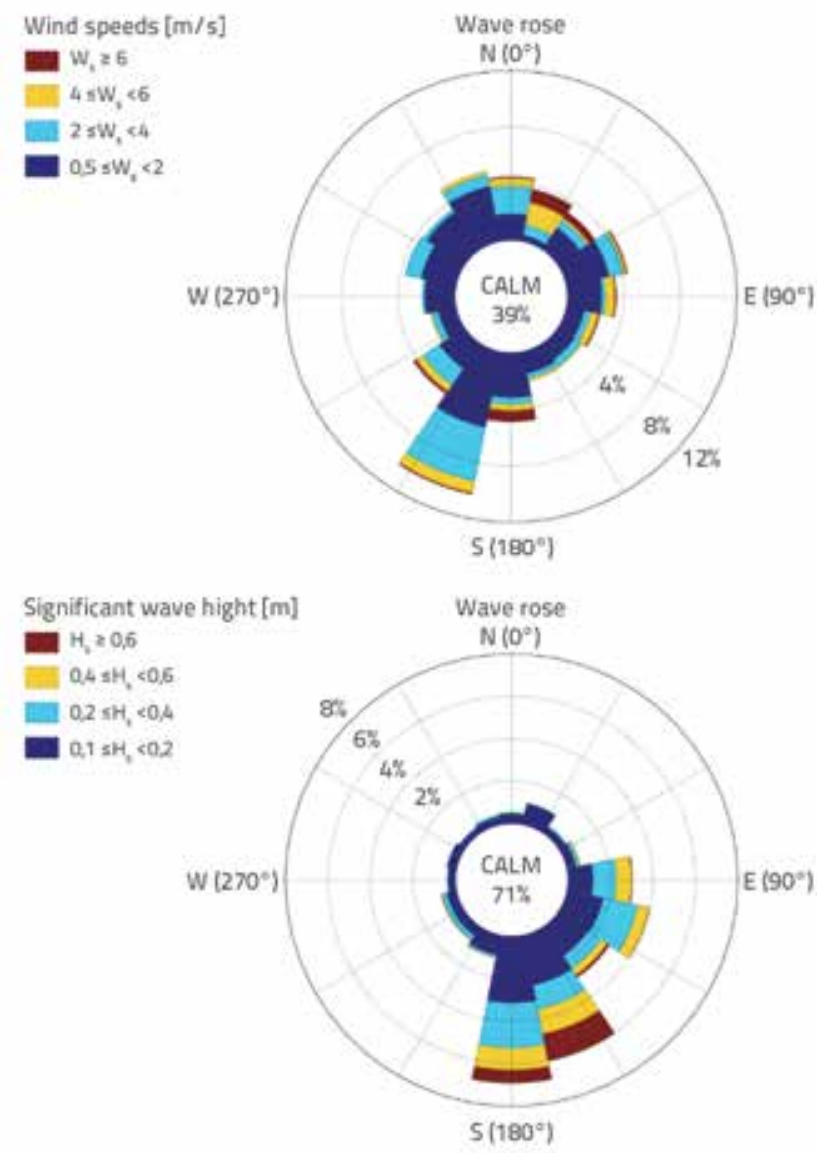

Figure 4. Wind rose and wave rose for the entire period of measurement (hourly averaged values of wind and wave parameters)

Therefore, the parts of the characteristic periods with northnortheast winds ( 5 and 6 ) that are affected by waves were not included in further analysis to isolate the wind effect. $A$ discrepancy between wind and wave directions was observed (Figure 4). Namely, winds from SSW (Figure 4) produce waves from the SSE direction. The explanation lies in a specific wind field in the northern part of Croatia. Previous metrological observation of the area detected a significant influence of the steep coast and mountains just behind the shoreline, which

Table 2. Characteristic periods during measurements

\begin{tabular}{|c|c|c|c|c|}
\hline Characteristic period & Start date (day.month.year., time) & End date (day.month.year., time) & Wind direction & Waves \\
\hline 1. & $19.2 .2017 ., 16: 00$ & $22.2 .2017 ., 22: 00$ & No wind & No \\
\hline 2. & $23.2 .2017 ., 13: 00$ & $25.2 .2017 ., 20: 00$ & SSW & Yes \\
\hline 3. & $28.2 .2017 ., 5: 00$ & $1.3 .2017 ., 17: 00$ & SSW & Yes \\
\hline 4. & $4.3 .2017 ., 7: 00$ & $6.3 .2017 ., 6: 00$ & NNE & No \\
\hline 5. & $7.3 .2017 ., 2: 00$ & $8.3 .2017 ., 1: 00$ & NNE & No \\
\hline 6. & $10.3 .2017 ., 5: 00$ & $11.3 .2017 ., 7: 00$ & No wind & No \\
\hline 7. & $14.3 .2017 ., 0: 00$ & $16.3 .2017 ., 9: 00$ & & \\
\hline
\end{tabular}


channel the winds in a direction parallel to the coastline. While measured winds approach the marina from the south-southeast, at open sea these winds come from a broader southeast and south-southwest direction and have a substantial fetch area of $20 \mathrm{~km}$, in which they can generate notable wind waves. When southern winds hit the mountainous coast, they are channelled in a south-southwest direction, parallel to the coastline. Winds blowing from the north-northeast have a small $5 \mathrm{~km}$ fetch area and the wind direction is parallel to the coast, which further disrupts wave generation.

The most frequent wind events come from the south-west (10 $\%$ ), while the strongest winds approach the area from the south and north-east direction ( $0.5 \%$ of the recorded hourly averaged wind velocities had a magnitude greater than $6 \mathrm{~m} / \mathrm{s}$ ) (Figure 4). The direction of north-northeast winds is normal to the marina entrance, which may cause a slightly higher impact to sea currents inside the marina to these winds. Calm winds (when the wind intensity is below $0.5 \mathrm{~m} / \mathrm{s}$ ) characterize $39 \%$ of the measuring period. Wave conditions were considered calm most of the time ( $71 \%$ of the observed period the significant wave height was below 0.1 meter), while the most frequent wave direction varied between east and south. In more prominent wave situations, waves arrived mainly from the south and the south-east (wave conditions with significant wave height above $0.6 \mathrm{~m})$. In relation to the culvert direction $\left(135^{\circ}\right)$, the incident wave angles mainly range between $-45^{\circ}$ and $+45^{\circ}$, with higher waves approaching at an angle between $+15^{\circ}$ and $+45^{\circ}$. Waves coming at an incident wave angle higher than $0^{\circ}$ are expected to have a smaller wave energy transmission and mass flow rate [24].

Sea level is presented from the bottom of the culvert. The top of the culvert is at a sea level of 1 meter corresponding to the diameter of the culvert (Figure 3 ). During the measurements, the tidal range was mostly about $0.4 \mathrm{~m}$, with the lowest observed value being $0.7 \mathrm{~m}$ and highest $1.6 \mathrm{~m}$ from the bottom of the culvert.

The sea water volume that passed through the culvert was regarded as an absolute integrative value during each tidal oscillation (flood and ebb). It was also assumed that old sea water, i.e. the water that exited the marina from the previous tide, did not return through the culvert from the surrounding sea (return flow (b) equals 0 [10]) and that the water entering the marina was immediately mixed within the basin. This is an acceptable assumption for small well-mixed basins [25]. The integrated volume during one tidal oscillation was then put into relation with the tidal prism of the marina (a commonly used simplified method for calculating the mean tidal prism is to multiply the mean tidal range and the water area at mean sea level - the sheltered area of the marina taken into calculation equals $40000 \mathrm{~m}^{2}$ ). This was done to estimate the amount of sea that passes through the culvert as related to the amount that circulates through the entire marina at each tide. The fraction of the tidal prism that passes through the culvert in calm times varies from $2 \%$ to $4 \%$. During characteristic periods with winds and waves, this value is significantly higher and can reach up to $12 \%$. As there are 8 culverts in Opatija Marina, the value of 96 $\%$ is obtained if we assume a linear scaling of volume passing through the culverts. This is naturally extremely high, and it is a consequence of different circulation generators like wind, waves, and tides (if there are winds and waves, the total volume of water circulating through the marina in one tidal oscillation exceeds $100 \%$ of the tidal prism). In calm characteristic periods, the combined flow of 8 culverts is equal to $24 \%$ of the tidal prism. This value points to a significant influence of culverts on sea circulation in the case of tidal oscillations.

As to the influence of sea level, the following two distinct regions can be detected (Figure 5): when the sea level is above 1 meter (the culvert is fully submerged in sea water) and below 1 meter (the culvert is partially submerged in sea water, leaving a part of the culvert filled with air). In the former case, the volume of water passing through the culvert is forced by tidal action only (characteristic periods 1 and 7) and it is up to two times lower compared to the latter case. The same effect is also observed for characteristic periods in which winds come from the north-east-north direction (characteristic periods 5 and 6), and the flow increases significantly with a decrease in water level below the top of the culvert. The influence of water level during characteristic period 6 is comparable to characteristic periods without wind (characteristic periods 1 and 7), when the flow increases two times with a decrease in water level. During characteristic period 5, the sea level never decreases below 1 $\mathrm{m}$, although there is still a striking trend of an increase in flow with a decrease in sea level. Nonetheless, wind (of different intensities) blowing from north-northeast can result in a three times higher flow in comparison to a non-wind characteristic period. This may be due to the drag of the water at the surface by the wind or by the appearance of a water surface tilt inside the marina, manifested in the situation in which the surface water at the leeward side of the breakwater is higher compared to the seaward side of the culvert. It can be observed that a maximum volume of $120 \mathrm{~m} 3$ passes through the culvert in one hour if the flow is forced by the tidal action only (characteristic periods 1 and 7 in Figure 5).

Field measurements have been used to calibrate an analytical model of pipe flow during characteristic periods without the presence of wind and waves in the marina. It is not uncommon for the entrance energy loss and exit energy coefficient to be the dominant energy loss mechanism in short pipes and culverts $[20,26]$. If the sea velocities outside the culvert are assumed to be negligible in comparison to the velocities inside the culvert, it is common to assign a value of 1 to the exit loss coefficient [20]. Previous research regarding hydraulic principles of culvert behaviour on waterways shows that the entrance loss coefficient can change with the change in water level in front of the culvert, especially for water levels below $H / D<$ $1.5 \mathrm{H}$ - water level measured from the bottom of the culvert; D - culvert diameter) $[21,22]$. The entrance loss coefficient increases with an increase in water level in most culvert entrance 
designs. Therefore, due to its varying nature, the entrance loss coefficient was chosen as the calibration parameter in this analysis. Guidebooks concerning culvert hydraulic design [27] often provide the following relationship for calculating the total energy loss:

$H=\left(k_{i z l a z}+k_{u l a z}+\frac{19,63 \cdot n^{2} \cdot L}{R^{1,33}}\right) \frac{V^{2}}{2 g}$

where:

$\mathrm{H}$ - total energy loss

$\mathrm{k}_{\mathrm{izlaz}}$ - exit loss coefficient (taken as a constant equal to 1)

$\mathrm{k}_{\mathrm{ulaz}}$ - entrance loss coefficient

$\mathrm{n}$ - Manning roughness coefficient for a culvert with uniform material on the full perimeter ( $n=0.013$ for concrete pipes)

L - culvert length (in Opatija Marina, L = $18 \mathrm{~m}$ )

$\mathrm{R}$ - hydraulic radius of the culvert

$\mathrm{V}$ - velocity inside the culvert

g - gravitational constant (equal to $9.81 \mathrm{~m} / \mathrm{s}^{2}$ ).

The velocity inside the culvert, as well as the hydraulic radius, change according to the sea level, and can be derived from the proposed analytical model that corresponds to the scatter data set measured in Opatija Marina for the culvert flow with tidal oscillations as the only generator of flow (Figure 5). Additionally, the total energy loss was assumed to be constant in all cases as there is no accurate data regarding the differences in sea level between the seaward and leeward sides of the breakwater. The total energy loss was assumed to be $0.15 \mathrm{~mm}$, leaving the entrance loss coefficient the only unknown variable in equation (1). Using equation (1) for varying sea levels, a calibrated coefficient for entrance energy loss can be derived as a function of sea elevation (Figure 5).

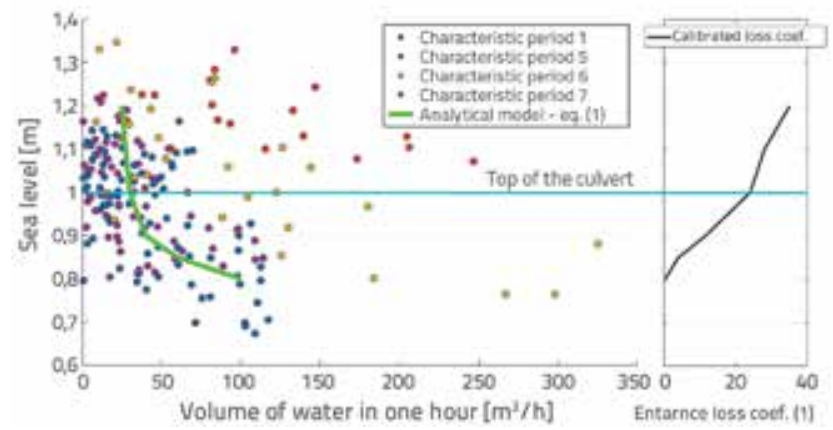

Figure 5. Measured volume of water passing through one culvert in one hour versus water level (characteristic periods without wind induced waves)

The calibrated values of the entrance loss coefficient for the flow inside the culvert vary greatly for different sea levels. The lowest and the highest computed values are 0.4 and 35 , respectively. The huge range of the coefficient is a consequence of several unpredicted effects. First of all, in culvert hydraulics on waterways it is expected for the flow to be in the direction of the culvert itself, which may not be the case in maritime circumstances. Sea currents in coastal areas mainly flow parallel to the coast and, in the case of Opatija Marina, this flow is perpendicular to the direction of the culvert (Figure 1). Previous research also shows that the loss coefficient can increase by about $48 \%$ depending on the level of damage to culverts [23]. Additionally, the entrance energy loss curve varied dramatically in previous studies on account of geometrical characteristics of the culvert and the obstruction, and so it can be expected that the rubble mound slope has a specific effect on the entrance loss coefficient curve $[21,22]$. While the aforementioned studies of culvert hydraulics considered fully turbulent flow, the flow through the culvert in Opatija Marina is not in the zone of complete turbulence, but rather in the transition zone between the laminar and turbulent flows [28]. The specific hydrodynamic conditions could also have an unanticipated impact on the calibrated entrance energy loss coefficient. The mentioned unaccounted effects are all currently included in the calibrated entrance loss coefficient curve (Figure 5).

The influence of water level with regard to vertical positioning of the culvert will be presented through a submergence coefficient (w). The coefficient is defined as the ratio of the hourly averaged water level measured from the bottom of the culvert upward to the culvert diameter. This ratio results in a dimensionless coefficient that can take into account variations in sea levels. It was established that water level exerts a great influence on the amount of water passing through the culvert. In consequence, it can be deduced that a higher ratio of hourly averaged wind magnitude and the corresponding submergence coefficient result in a higher flow rate (Figure 6).

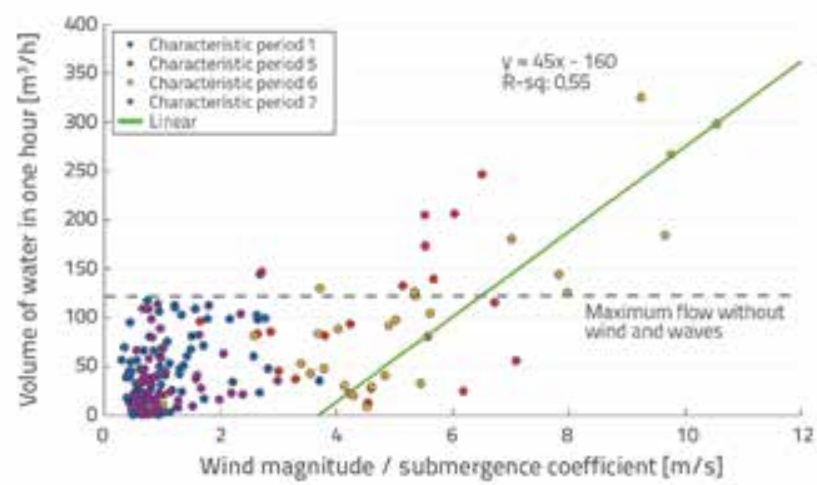

Figure 6. Measured volume of water passing through one culvert in one hour versus ratio of wind magnitude and submergence coefficient (characteristic periods without wind induced waves)

During calm characteristic periods (characteristic periods 1 and 7), the ratio never increases above the value of 4 because the wind magnitudes are low. Only during wind situations, the ratio increases above the value of 4 . However, only ratios higher than 6 are capable of impacting the amount of volume of water that 
passes through a culvert. Linear approximation can be made to determine how rapidly does the increase of the ratio result in the increase of the volume passing through the culvert. Only the data points with the ratio greater than 4 were taken into account when creating the linear estimate. An increase in the ratio by a value of $1 \mathrm{~m} / \mathrm{s}$ results in a $45 \mathrm{~m}^{3} / \mathrm{h}$ increase in the flow through the culvert. It is the authors' hypothesis that the wind duration has a significant impact on the observed system. In consequence, the use of wind duration in conjunction with the already mentioned ratio should yield more accurate results. However, this proves difficult when analysing field data as the wind is constantly changing in nature. Wind duration should be explored using extensive tests with a numerical model.

In characteristic periods where wind approaches from the south-southwest, there is no visible correlation between the ratio of wind magnitude and submergence coefficient with the volume passing through the culvert (Figure 7). Therefore, the flow inside the culvert cannot be predicted using the wind data alone. Other generators of flow should be taken into consideration, the most apparent one being waves. in periods during which waves appear at the end north-northeast wind events, the flow inside the culvert also proves to be very unpredictable when based on the previously presented linear approximation (Figure 6). Recorded flows are nonetheless even greater than in characteristic periods with north-northeast wind, reaching values about four times greater than those in calm situations. Water hydrodynamics in culverts influenced by a combination of wind and waves should further be examined based on 3D numerical models.

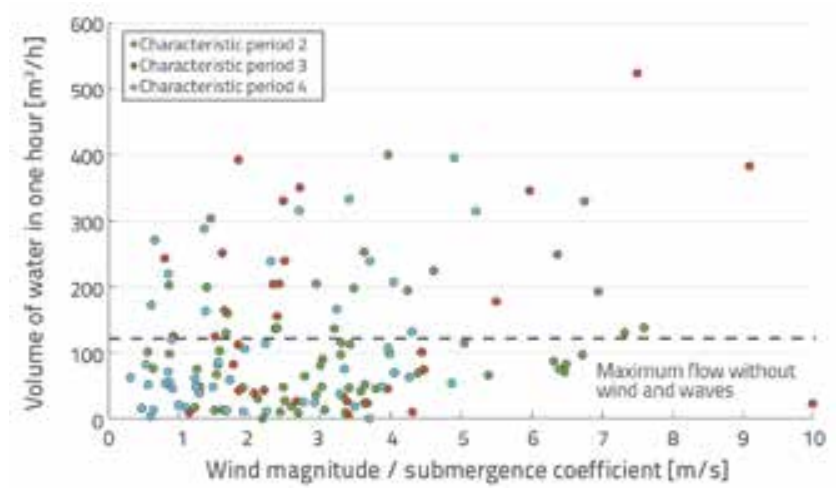

Figure 7. Measured volume of water passed through one culvert in one hour versus the ratio of wind magnitude and submergence coefficient (Situations characteristic periods with wind induced waves from south-southwest)

It should be brought to the reader's attention that there can be a considerable wave energy transmission through the culvert and into the basin of the marina. Therefore, horizontal and vertical positioning of culverts should be defined based on local wave conditions. Appropriate attention should also be paid to the problem of high velocities of water entering the basin through culverts during wave events, so as to avoid the appearance of large vortices in the marina.

\section{Conclusion}

Reduced water quality is a prominent issue in areas with low tidal oscillations, such as in all parts of the Mediterranean Sea. It has already been established that sufficient water renewal improves the quality of water inside harbours. A sufficient level of water exchange is defined as the water exchange that ensures that pollutant concentrations inside a marina are below the level considered critical for the ecosystem (e.g. critical concentration of algal bloom or dissolved oxygen). Flushing culverts are a standard engineering solution for improving sea circulation and water renewal in low tide areas. A large one-and-a-half-monthslong campaign of field measurements was conducted in Opatija Marina situated in the northern part of the Adriatic Sea. The campaign was aimed at gaining better understanding of the underlying processes that generate water renewal.

During calm wind periods, roughly $3 \%$ of the tidal prism circulates through the culvert in one tidal oscillation. With 8 culvert presents in the marina and assuming linear scaling of flow, this value rises up to $24 \%$, which by itself presents a significant influence on water circulation in the marina. Wind and wave generators increase the tidal prism fraction by up to four times. This value should be taken with caution because, considering wind and wave circumstances, the total circulation is much higher than the tidal prism.

Sea levels greatly influence the quantity of water flowing through the culvert. If the sea decreases to a level that is below the top of the culvert, the flow increases by up to two times, both in the calm and wind events. An analytical model applied in culvert hydraulics was used to make comparisons with the measured data. The entrance loss coefficient was used as a calibration variable. The loss coefficient varied greatly from 0.4 to 35 . Several unaccountable effects could have a significant influence on the calibrated entrance energy loss coefficient. The quantity of water flow can be predicted in characteristic periods, without incident wave fields, by means of a linear approximation. The ratio of wind magnitude to submergence coefficient should be at least 6 (assuming the sea level is at the top of the culvert and wind velocity is $6 \mathrm{~m} / \mathrm{s}$ ), and so the wind can influence the flow in the marina and consequently, in the culvert. This estimate cannot be applied to characteristic periods in which the wind approaches from the south-southwest direction (waves from south-southeast are present), because nonlinear interaction between the wind and waves, effecting the flow in the culvert, is significantly more complex.

\section{Acknowledgements}

This work has been fully supported by the Croatian Science Foundation under the project number UIP-2014-09-6774. 


\section{REFERENCES}

[1] Di Franco, A., Graziano, M., Franzitta, G., Felline, S., Chemello, R., Milazzo, M.: Do small marinas drive habitat specific impacts? A case study from Mediterranean Sea, Mar. Pollut. Bull, 62 (2011), pp. 926-933. https://doi.org/10.1016/j.marpolbul.2011.02.053.

[2] Gaitanis, C.K., Douka, E., Tsoukala, V.K., Stamou, A.I., Moutzouris C.I.: Dissolved Oxygen Transmission in Harbor Basins Through Flushing Culverts, in: Proc. $11^{\text {th }}$ Int. Conf. Environ. Sci. Technol., pp. 285-292, 2009.

[3] Tsoukala, V.K., Gaitanis, C.K., Stamou, A.I., Moutzouris, C.I.: Wave and dissolved oxygen transmission analysis in harbors using flushing culverts: An experimental approach, Glob. Nest J. 12 (2010) 152-160.

[4] Schwartz, R.A., Imberger, J.: Flushing Behaviour of a Coastal Marina, Coast. Eng. Proc., 1 (1988), pp. 2626-2640.

[5] Ferreira, J.G., Wolff, W.J., Simas, T.C., Bricker, S.B.: Does biodiversity of estuarine phytoplankton depend on hydrology, Ecol. Modell. 187 (2005), https://doi.org/10.1016/j.ecolmodel.2005.03.013.

[6] Borja, Á., Rodríguez, J.G., Black, K., Bodoy, A., Emblow, C., Fernandes, T.F., Forte, J., Karakassis, I., Muxika, I., Nickell, T.D., Papageorgiou, N., Pranovi, F., Sevastou, K., Tomassetti, P., Angel, D.: Assessing the suitability of a range of benthic indices in the evaluation of environmental impact of fin and shellfish aquaculture located in sites across Europe, Aquaculture, 293 (2009). https://doi.org/10.1016/j.aquaculture.2009.04.037.

[7] Fischer, H.B., List, E.J., Koh, R.C.Y., Imberger, J., Brooks, N.H.: Mixing in inland and coastal waters, Acad. San Diego Calif, 114 (1979), pp. 315-316. https://doi.org/10.1017/S002211208223028X.

[8] DiLorenzo, J.L., Ram, R.V., Huang, P., Najarian, T.O.: Pollution susceptibility of well-mixed tidal basins, J. Waterw. Port, Coastal, Ocean Eng, 120 (1994), pp. 404-422.

[9] Nece, B.R.E., Asce, F.: Planform Effects on Tidal Flushing, J. Waterw. Port, Coast. Ocean Eng., 110 (1984), pp. 251-269. https://doi.org/10.1061/(ASCE)0733-950X(1984)110:2(251).

[10] Sanford, L.P., Boicourt, W.C., Rives, S.R.: Model For Estimating Tidal Flushing of Small Embayments, J. Waterw. Port, Coastal, Ocean Eng., 118 (1992), pp. 635-654.

[11] Nece, B.R.E., Asce, F.: Planform effects on tidal flushing of marinas, J. Waterw. Port, Coast. Ocean Eng., 110 (1984), pp. 251-269. https://doi.org/10.1061/(ASCE)0733-950X(1984)110:2(251).

[12] Falconer, R.A., Guoping Yu.: Effects of depth, bed slope and scaling on tidal currents and exchange in a laboratory model harbour, Proc. Inst. Civ. Eng., 91 (1991) 2, pp.561-576.

[13] US Army Corps of Engineers, Coastal Engineering Manual, 2002.

[14] Tsoukala, V.K., Moutzouris, C.I.: Wave transmission in harbors through flushing culverts, Ocean Eng., 36 (2009), pp. 434-445. https://doi.org/10.1016/j.oceaneng.2009.01.005.
[15] Katsardi, V., Boundris, G., Tsoukala, V.K., Belibassakis, K.A.: Study of wave transformation due to flushing culverts in coastal structures, Proc. Int. Offshore Polar Eng. Conf., 4 (2012), pp. $1356-1363$.

[16] Umgiesser, G., Ferrarin, C., Cucco, A., De Pascalis, F., Bellafiore, D., Ghezzo, M., Bajo, M.: Comparative hydrodynamics of 10 Mediterranean lagoons by means of numerical modeling, J. Geophys. Res. Ocean, pp. 9026-9032, 2014, https://doi. org/10.1002/2014JC010066.Received.

[17] Cucco, A., Umgiesser, G.: Modeling the Venice Lagoon residence time, Ecol. Modell, 193 (2006), pp. 34-51, https://doi. org/10.1016/j.ecolmodel.2005.07.043.

[18] Canu, D.M., Solidoro, C., Umgiesser, G., Cucco, A., Ferrarin, C.: Assessing confinement in coastal lagoons, Mar. Pollut. Bull., 64 (2012), pp. 2391-2398, https://doi.org/10.1016/j. marpolbul.2012.08.007

[19] Stagonas, D., Müller, G., Magagna, D., Warbrick, D.: Fundamental investigation of water flow in harbors through a flushing culvert, in: Water Eng. a Sustain. Environ. Ranging, pp. 7288-7295, 2009.

[20] Tullis, B.P., Robinson, S.C.: Quantifying culvert exit loss, J. Irrig. Drain. Eng., 134 (2008), https://doi.org/10.1061/(ASCE)07339437(2008)134:2(263).

[21] Tullis, B.P., Anderson, D.S., Robinson, S.C.: Entrance loss coefficients and inlet control head-discharge relationships for buried-invert culverts, J. Irrig. Drain. Eng., 134 (2008), https://doi. org/10.1061/(ASCE)0733-9437(2008)134:6(831).

[22] Smith, C.D., Oak, A.G.: Culvert inlet efficiency, Can. J. Civ. Eng., 22 (1995).

[23] Keils, J.: Hydraulic performance of damaged-end corrugated steel pipe culverts, Can. J. Civ. Eng., 35 (2008), https://doi.org/10.1139/ L08-055.

[24] Tsoukala, V.K., Moutzouris, C.I.: A 3-D experimental study on the beneficial role of flushing culverts in sea water quality, in: Proc. Coast. Eng. Conf., 2009.

[25] Monsen, N.E., Cloern, J.E., Lucas, L.V., Monismith, S.G.: A comment on the use of flushing time, residence time, and age as transport time scales, Limnol. Oceanogr., 47 (2002), pp. 1545-1553, https:// doi.org/10.4319/lo.2002.47.5.1545

[26] Board, E.: National Academies of Sciences and Medicine, Hydraulic Loss Coefficients for Culverts, The National Academies Press, Washington, DC, 2012, https://doi.org/10.17226/22673.

[27] U.S. Department of Transportation - Federal Highway Administration, Hydraulic design of highway culverts, Third Edit, 2012.

[28] Fung, Y.C.: Biomechanics - Motion, flow, stress and growth, Springer-Verlag, New York, 1990. 